\title{
Current Literature - Neue Literatur - Nouveautés
}

\section{2}

Altman, S. A.: Primate social behavior. Curr. Anthrop. 3: 100 (1962).

Ankel, F.: Vergleichende Untersuchungen über die Skelettmorphologie des Greif-schwanzes südamerikanischer Affen (Platyrrhina). Z. Morph. ökol. Tiere 52: 131-170 (1962).

Biegert, J.; Hofer, H. und Starck, D. (Hg.): Festschrift Adolph Hans Schultz zum 70. Geburtstag gewidmet. (Karger, Basel/New York 1962). (Bibliotheca Primatologica, Fasc. 1).

Bone, E. L.: Rythmes evolutifs compares des liominidés et des mammifères pleistocenes. Bibl. primat. vol. 1, pp. 71-92 (Karger, Basel/New York 1962).

Buettner-Januscii, J.: Antihuman sera and primate erythrocytes. Ann. N. Y. Acad. Sci. 97: 9-14 (1962).

Buettner-Janusch, J. and Andrew, R. J.: The use of the incisors by primates in grooming. Amer. J. phys. Anthrop. 20: 127-130 (1962).

Byck, R. and Hearst, E.: Adjustment of monkeys to five continuous days of work. Science 138: 43-44 (1962).

Chopra, S. R. K.: The innominate bone of the Australopithecinae and the problem of erect posture. Bibl. primat. vol. 1, pp. 93-102 (Karger, Basel/New York 1962).

Coppens, Y.: Découvertes d'un Australopithéciné dans le Villafranchien du Tchad. Coll. Int.

Centre Nat. Rech. Sci. no. 104: 455-460 (Paris 1962).

Cowgill, U. M.; Bishop, A.; Andrew, R. J. and Hutchinson, G. E.: An apparent lunar periodicity in the sexual cycle of certain prosimians. Proc. Nat. Acad. Sci. 48: 238-241 (1962).

Dart, R. A.: The gradual appraisal of Australopithecus. In: Evolution und Homini-sation, pp. 141-156 (Fischer, Stuttgart 1962).

Dart, R. A.: The Makapansgat pink breccia australopithéciné skull. Amer. J. phys. Anthrop. 20: 119-126 (1962).

Dart, R. A.: A cleft adult mandible and the nine other lower jaw fragments from Makapansgat. Amer. J. phys. Anthrop. 20: 267-286 (1962).

Dart, R. A.: From cannon-bone scoops to skull bowls at Makapansgat. Amer. J. phys. Anthrop. 20: 287-296 (1962).

Drawert, F.; Kuhn, H. J. und Rapp, A.: Reaktions-Gaschromatographie III.

Gaschromatographische Bestimmung der niederflüchtigen Fettsäuren im Magen von

Schlankaffen (Colobinae). Hoppe-Seylers Z. physiol. Chem. 329: 84-89 (1962).

Ebner, F. and Myers, R. E.: Direct and transcallosal induction of touch memories in the monkey. Science 138: 51-52 (1962).

Ellis, R. A. and Montagna, W.: The skin of primates. VI. The skin of the Gorilla (Gorilla gorilla). Amer. J. phys. Anthrop. 20: 79-94 (1962).

Emlen, J. T.: The display of the Gorilla. Proc. amer. Philos. Soc. 106: 516-519 (1962).

136

Current Literature 
Eyquem, A.; Podliachouk, L. and Millot, P.: Blood groups in chimpanzees, horses, sheep, pigs, and other mammals. Ann. N. Y. Acad. Sci. 97: 320-328 (1962).

Freedman, L.: Growth of muzzle lenght relative to calvaria lenght in Papio. Growth 26: 117-128 (1962).

Freedman, L.: Quantitive features of the deciduous dentition of Papio ursínus. Sth. Afr. J. Sci. 58: 229-236 (1962).

French, G. M.: Spatial discontiguity in monkeys with lesions of the frontal cortex. Science 135: 728-729 (1962).

Frisch, J. E.: Neuer Fund eines fossilen Hominoiden in Kenya und dessen Bedeu-deutung für unsere Kenntnis der Hominoiden-Evolution. Anthrop. Anz. 25: 298-301 (1961/62).

Frisch, J. E.: The reduction of the third molar in hominoid evolution. Proc. 30th ann. Meet. amer. Ass. phys. Anthrop. 1961; Amer. J. phys. Anthrop. 20: 68 (1962).

Gazin, C. L.: A further study of the lower eocene mammalian faunas of southwestern Wyoming. Smithsonian misc. Coll. 144: 1-98 (Washington 1962).

Genet-Varcin, E.: Evolution de la couronne de la seconde prémolaire inférieure chez les hominidés. An. Paléont. 48: 57-82 (1962).

Goettert, L.: Chromosomenstudien an Menschenaffen. Naturw. Rundsch. 15: 154 (1962).

Goettert, L.: Farbtüchtigkeit bei Halbaffen. Naturw. Rundsch. 15: 157 (1962).

Goodman, M.: Species differences in the distribution of transferrin phenotypes in macaques and other higher primates. Proc. 30th. ann. Meet. amer. Ass. phys. Anthrop. 1961; Amer. J. phys. Anthrop. 20: 68 (1962).

Goodman, M.: Evolution of the immunologic species specificity of human serum proteins. Human Biol. 34: 104-150 (1962).

Gremiatskij, M. A.: Primates. In: Grundzüge der Paläontologie. Handbuch der Paläontologie und Geologie der UdSSR.: Säugetiere, pp. 90-108 (Moskau 1962).

Hanson, G. and Montagna, W.: The skin of primates. XII. The skin of the owl monkey (Aòtus trivirgatus). Amer. J. phys. Anthrop. 20: 421-430 (1962).

Harlow, H. F. and Harlow, M. K.: Social deprivation in monkeys. Amer. Sc. 207: 136-146 (1962).

Hashiguchi, K.: On the muscles of the thigh in Macacus cyclopsis. Okaj. Fol. Anat. Jap. 38: 435454 (1962).

Heberer, G.: Pre-hominid finds in South and East Africa. Germany - Mag. Federal Republic, vol. 7, p. 4 (1962).

Heberer, G.: Die Oldoway (Olduvai)-Schlucht (Tanganyika) als Fundort fossiler Hominiden.

Bibl. primat. vol. 1, pp. 103-119 (Karger, Basel/New York 1962).

Hediger, H. und Zweifel, F.: Primaten-ethologische Schnappschüsse aus dem Zürcher Zoo. Bibl. primat. vol. 1, pp. 252-276 (Karger, Basel/New York 1962). 